\section{Row erupts over evacuation plans for Mount Vesuvius}

London. Members of an Italian government commission given responsibility for setting up a contingency plan for the possible eruption of Mount Vesuvius have fallen out over the final report, which one member describes as being over-ambitious and scientifically flawed, and thus unworkable.

Giuseppe Luongo, professor of physical volcanology at the University of Naples, says the plan claims that volcanologists can predict an eruption within 20 days. But he argues that the plan is based on flawed data and was drawn up without peer review, and with virtually no input from the local population.

"I am sad to see millions of taxpayer dollars being wasted on producing [this plan], and also regret that its authors appear ignorant of current scientific literature on the subject", says Luongo, a former director of the Vesuvius

Observatory. "I would like to know who are these scientists who think they can issue a volcanic eruption forecast 20 days in advance. In my experience of similar volcanoes - for example, Mount St Helens in 1980 and Pinatubo in 1991 - scientists are very reluctant to issue such forecasts without objective data."

The plan, issued by the Department of Civil Protection at the end of last month, assumes that volcano monitoring stations will remain operational up to a few days preceding an eruption. Luongo says that it apparently makes no allowances for false alarms, and fails to outline a clear chain of command. Furthermore, the plan was developed using the 1631 eruption of Vesuvius as a template, and Luongo says such an assumption could be a mistake as that eruption, which killed several thousand people, remains highly controversial among volcanologists.

But Lucia Givetta, director of the Vesuvius Observatory and a member of the commission, disagrees. She says that the volcano has always emitted distinct, characteristic precursor signals before an eruption. The most recent eruption - which took place during the Second World War in 1944 was accurately predicted by one of her predecessors, Giuseppe Imbi, "using just one instrument", she says. "Unfortunately, the soldiers didn't listen to him, and no countermeasures were taken."

Givetta says the commission's data are no secret, as they are unchanged from the previous commission's report in 1992. "It has been extensively discussed and debated. This plan was not just born yesterday, it is the result of almost five years' hard work."

Nevertheless Luongo, despite being the only member of the five-person commission to vote against the plan, claims to have the support of many volcanologists at Italian universities who, he claims, are unable to speak out openly. One who did so - Flavio Dobran, a former professor of volcanology at the universities of Rome and Pisa claims to have had his research grant terminated after publishing a paper (see Nature $367,551-554 ; 1994$ ) that defied the orthodox

\section{IMAGE \\ UNAVAILABLE FOR COPYRIGHT REASONS}

get the science as accurate as possible. The rest we leave to politicians. Ehsan Masood
'Ig Nobel' ceremony reaches new heights and moves to Harvard

Boston. The Fifth Annual 'Ig Nobel' Prize Ceremony, held on 6 October, was a night of many firsts. The proceedings were televised live via the Internet, a feat never previously attempted. It featured the world premiere of the "Interpretive Dance of the Nucleotides", featuring the Nicola Hawkins Dance Company and five Nobel prizewinners.

Sheldon Glashow and harpist Deborah Henson-Conant performed a second world premiere, Cymbalic Duet in $B^{\#}$ Major with Psychological Overtones. And in yet another first, the ceremony was held at Harvard University rather than at neighbouring Massachusetts Institute of Technology (MIT), site of the four previous 'Igs'.

The change of venue was due to a rift earlier in the year between Marc Abrahams, editor of the Annals of Improbable Research (AIR) - a sponsor of this year's and last year's 'Ig' ceremony - and the MIT Museum, the previous 'Ig' co-sponsor which had also been publishing the Annals.

The falling-out was surprising in view of the gala celebration at the museum in December 1994 of the release of AIR's first issue, when many were saying that MIT was "the perfect home" for a magazine such as AIR and the associated award ceremony.

Both sides were tight-lipped about the controversy, which apparently revolved around the failure of Abrahams and the museum to agree on a contract for the continued publication of the magazine. MIT sources also claim that the museum staff had grown weary of the amount of time spent on the annual Ig event.

Abrahams has since published and edited the magazine on his own, finding a new home for the Igs - Harvard's Lowell Lecture Hall - with help from Glashow and fellow Nobel laureates Dudley Herschbach and William Lipscomb. Two student organizations - the Harvard Computer Society and Tangents (the Harvard-Radcliffe Mathematical Bulletin) - agreed to co-sponsor the event.

The 1995 Ig festivities, built around the theme of DNA, contained the usual assortment of jokes, outbursts and 'spontaneous combustion'. The five Nobel prizewinners participated directly, while six others sent taped messages to the winners and audience.

Why do these distinguished scholars subject themselves to the often embarrassing moments that make up the Igs? "This is a chance to put some fun back into science," Herschbach says. "Scientists do have a lot of fun, and it's important that the public, and especially young people, realize that. We aren't just a bunch of super-nerds with no sense of humour."

Steve Nadis 